\title{
Fen Bilgisi Öğretmen Adaylarının Gazetelerde Yer Alan Sosyo-Bilimsel Konulara Yönelik Farkındalıklarının İncelenmesi ${ }^{*}$
}

\author{
Investigation of Pre-Service Science Teachers' Awareness of \\ Socio-Scientific Issues Appearing in Newspapers
}

\author{
Nurhan ÖZTÜRK ${ }^{\star *}$
}

\author{
Hilal ERABDAN ${ }^{\star * *}$
}

Öz. Bu çalışmada fen bilgisi öğretmen adaylarının fen okuryazarlığı için bir ön koşul niteliği olarak ifade edilebilecek sosyo-bilimsel konularla ilgili farkındalıklarının tespit edilmesi amaçlanmıştır. Nitel araştırma desenlerinden durum çalışması deseninin kullanıldığı araştırmanın çalışma grubu, amaçlı örnekleme yöntemine göre belirlenmiş 15 (13 kadın, 2 erkek) 3.sınıf öğretmen adayından oluşmaktadır. Uygulama süreci iki aşamadan oluşmaktadır. Illk aşamada, araştırmacılar tarafından 2016 yılına ait gazete tirajları dikkate alınarak en yüksek tiraja sahip dört ulusal gazete bir ay boyunca takip edilmiş ve incelenen 120 gazete haber metni arasından fen ile ilgili olan haber metinleri belirlenmiştir. Araştırmanın ikinci aşaması ise öğretmen adaylarının aktif katılımı ile planlanmış bir uygulama sürecinden oluşmaktadır. Adaylar, bir konunun sosyo-bilimsel olmasında hangi özelliklere sahip olması gerektiğini belirtmişler ve gazetelerde yer alan haber metinleri arasından sosyobilimsel konuları tespit etmişlerdir. Araştırma sonunda, öğretmen adaylarının büyük bir kısmının, haber metinlerinde yer alan fen kavramlarını belirleyebildikleri ve gazetelerde yer alan sosyo-bilimsel konuların çoğunu tespit edebildikleri görülmüştür. Adayların, tespit ettikleri sosyo-bilimsel konuları seçme nedenleri olarak; konuların tartışmaya açık olması, güncel olması ve bireyi ikileme düşürmesi gibi gerekçeler öne sürdükleri belirlenmiştir.

Anahtar Kelimeler: Sosyo-bilimsel konular, fen bilgisi öğretmen adayları, fen okuryazarlık, fen kavramları, gazete.

\begin{abstract}
The purpose of this study was to determine pre-service science teachers' awareness of socio-scientific issues that are considered to be the pre-requisite of scientific literacy. The sample of this qualitative research is comprised of 15 thirdyear (junior) pre-service science teachers (13 females and 2 males) who were selected using purposive sampling method. This research consists of two phases. In the first phase researchers followed four newspapers with the highest circulations rate for a month in 2016 and, specific articles those are related to the science were selected after the evaluation of 120 newspaper articles. The second phase was an application process carried out based on the active involvement of pre-service science teachers. This application process included determining the science concepts in the newspapers, the reasons of labelling an issue as socio-scientific, and determining the socio-scientific concepts in these newspapers. The findings of this study revealed that most of the pre-service science teachers were able to determine the science-related concepts in the newspaper articles as well as majority of them were able to determine the headings regarded as socio-scientific issues. Pre-service science teachers explained some of their reasons, as issues being open to dispute, being up-to-date, and leading individuals to experience dilemmas for their selection of socio-scientific issues.
\end{abstract}

Keywords: Intelligence, Organizational intelligence, Organizational intelligence dimensions, Primary school.

\section{Toplumsal Mesaj.}

$\mathrm{Bu}$ çalışmada fen bilgisi öğretmen adaylarının fen okuryazarlığı için bir ön koşul niteliği olarak ifade edilebilecek sosyo-bilimsel konularla ilgili farkındalıklarının tespit edilmesi amaçlanmıştır. Araştırma sonunda, ögretmen adaylarının büyük bir kısmının, haber metinlerinde yer alan fen kavramlarını belirleyebildikleri ve gazetelerde yer alan sosyobilimsel konuların çoğunu tespit edebildikleri görülmüştür.

Public Interest Statement.

The purpose of this study was to determine pre-service science teachers' awareness of socioscientific issues that are considered to be the prerequisite of science literacy. The findings of this study revealed that most of the pre-service science teachers were able to determine the science-related concepts in the newspaper articles as well as majority of the pre-service teachers were able to determine the headings regarded as socio-scientific issues.

\footnotetext{
* Bu çalışmanın bir bölümü “26. International Conference on Educational Sciences” isimli kongrede sunulmuştur.

** Orcid ID: http://orcid.org/0000-0001-8624-3609, Dr. Öğr. Üyesi, Sinop Üniversitesi Eğitim Fakültesi, Matematik ve Fen Bilimleri Eğitimi Bölümü, Fen Bilgisi Eğitimi Anabilim Dalı, nurhanozturk@sinop.edu.tr

*** Orcid ID: http://orcid.org/0000-0001-8925-1428, Yüksek Lisans Öğrencisi, Sinop Üniversitesi, Fen Bilimleri Enstitüsü, Fen Bilgisi Eğitimi Programı, h.erabdan@hotmail.com
} 


\section{GíRiş}

Günümüz bilgi çağında bilim ve teknolojideki gelişmeler her geçen gün hızla artmakta ve bireyleri bu gelişim içinde doğru bilgiye ulaşma gayreti içinde bırakmaktadır. Bu süreçte özellikle medyanın etkisi ile bilimsel konular toplumun gündemini daha çok meşgul edebilmektedir. Örneğin; genetik kopyalama, küresel ısınma, ötanazi, aşı, alternatif yakıtlar, nükleer santraller ve hidroelektrik santraller gibi bilimsel, tartışmalı ve güncel konuların sayısı gün geçtikçe artmakta ve nihai olarak ulaşılan kararların toplumun bölgesel ve küresel olarak geleceğini etkileyeceğinden dolayı bu konular önemli konular olarak görülmektedir (Chang Rundgren ve Rundgren, 2010; Sadler, 2004a; Topçu, 2017). Genellikle etik ve ahlakla ilgili, ikilemler içeren ve bireylerin üzerinde kesin bir fikir birliğine varamadıkları (Kolstø, 2001a; Nielsen, 2012; Sadler ve Zeidler, 2004; Sadler, 2004b; Sadler, Amirshokoohi, Kezampouri ve Allspaw, 2006; Walker ve Zeidler, 2007), karmaşık, çözülmeyi bekleyen, açık-uçlu, tartışmaya açık, çekişmeli ve tek bir cevabı olmayan (Sadler, 2004a; Sadler ve Zeidler, 2005a; 2005b; Topcu, 2011) ve sosyal yaşamda bir öneme sahip olan bilimsel konular Sosyo-bilimsel Konular (SBK) olarak tanımlanmaktadır (Topçu, 2017). Bu bilimsel konular sadece belirli alanlarda uzmanlıkları olan bilim insanlarını değil tüm toplumu oluşturan bireylerin dikkatini çeken konulardır (Fleming, 1986; Zeidler, Walker, Ackett ve Simmons, 2002). Bu durum, toplumların geleceğini etkileyen konular hakkında fikir sahibi olan, araştıran, sorgulayan, analiz edebilen, değerlendirebilen ve karar verebilen fen okuryazar bireylerin yetiştirilmesinin gerekliliğini karşımıza çıkarmaktadır. Birçok fen eğitimcisi bu konulara fen derslerinde yer verilmesi üzerinde önemle durmuş (Driver, Newton ve Osborne, 2000; Kolstø, 2001b; Topçu, Muğaloğlu ve Güven, 2014) ve feni toplumdan ayrı bir disiplin olarak düşünmek yerine fen programlarında yer almasına ilişkin daha önceki yıllarda çeşitli girişimlerde bulunulmuştur (Sadler, 2004a). Bu girişimler ülkemizde de yansımasını bulmuş ve program çalışmalarında revizyona gidilmiştir. 2005 Fen ve Teknoloji Dersi Öğretim Programı ile 2013 ve 2018 Fen Bilimleri Dersi Öğretim Programları'nın vizyonu, "tüm öğrencilerin fen okuryazar birey olarak yetiştirilmesi" şeklinde belirlenmiş ve programda belli temalar altında açıklanmıştır (MEB, 2006; 2013; 2018). Bireylerin fen okuryazar olması ile ilgili çeşitli tanımlara gidilmiştir. Örneğin; Ulusal Fen Eğitim Standartları fen okuryazarlık kavramını bir kişinin bir bilimsel konu ile ilgili ulusal ve yerel açıdan vereceği kararlarda konuların farkında olma, kararın altında yatan gerekçeleri bilimsel ve teknolojik olarak değerlendirebilme olarak tanımlamaktadır (NRC, 1996). Miller'e (1998) göre fen okuryazar birey, günlük gazeteler veya dergileri okumada intiyaç duyulan bilimsel kavramları anlayan ve fen ve teknoloji ile ilgili tartışmaları değerlendirebilen bireydir. MEB (2017)'de ise fen okuryazar bir bireyin, araştıran, sorgulayan, bir konuda karar veren, birden fazla bakış açısı ile düşünen, problem çözebilen ve sürdürülebilir kalkınma bilinciyle yaşam boyu öğrenen aktif olma özelliği göstermesi beklenmektedir. Cooper (2011) ise fen okuryazarlık anlamında yeterliğe sahip olmayan öğrencilerin popüler medyada karşılaştıkları ilk bilgiye ya da en sık rastladıkları bilgiye doğrudan inandıkları ve konu hakkında var olan çatışmayı göz ardı ettiklerini ifade etmektedir. Yapılan tanımlardan da anlaşılacağı üzere fen okurayzar bir birey yetiştirmenin çıktılarının gerek yerel gerek bölgesel gerekse de Dünya çapında önemli olduğu düşünülmektedir. Fen okuryazar birey yetiştirmede önemli bağlam oluşturan ve ülkemizde fen programlarında yapılan önemli adımlardan biri de sosyo-bilimsel konuların 2013 Fen Bilimleri Dersi Öğretim Programı'nın "Fen-Teknoloji-Toplum ve Çevre" ve 2017 Fen Bilimleri Dersi Öğretim Programı́nın "Fen-Mühendislik-Teknoloji-Toplum ve Çevre" öğrenme alanlarına yerleştirilmesidir (MEB, 2013; 2017). Geçtiğimiz son on yıla bakılırsa yapılan pek çok çalışmada da bireyin fen okuryazar olarak yetiştirilmesinde SBK'nın fen eğitiminde önemli bir yer edindiği ve uygun bir bağlam oluşturduğu vurgulanmaktadır (Chang vd., 2010; Zeidler vd., 2002; Zeidler, Sadler, Simmons ve Howes, 2005; Zeidler ve Sadler, 2011). SBK, topluma farklı şekillerde taşınabilmektedir. Bilimsel kaynaklar, çevre, uzmanlar gibi birçok kaynak işlev görmektedir. Zira günlük hayatımızın vazgeçilmez en önemli organı olan popüler medya bu konuların toplum gündemine taşınmasında önemli görev üstlenmiştir. Öztürk, Eş ve Turgut (2017)'a göre toplum ile SBK arasında köprü görevi gören medyanın SBK-bilim ve toplum ile ilişkisi Şekil 1'de açıklanmaya çalışılmıştır: 


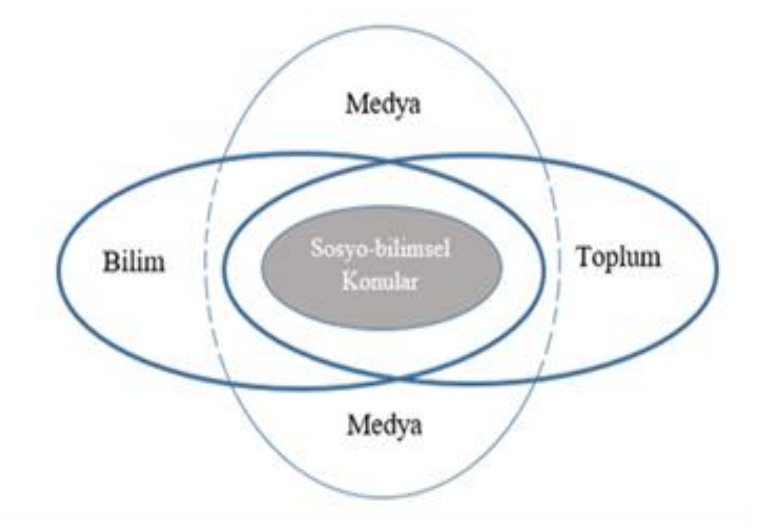

Şekil 1. Sosyo-Bilimsel Konular-Bilim-Toplum-Medya İlişkisi (Öztürk vd., 2017)

Şekil 1'de görüldüğü üzere, bilim ve toplumu ilgilendiren SBK medyanın bütüncül olarak gündeminde yer almaktadır. Nitekim SBK etkileşimli tartışma sağlaması bakımından medya aracıllı̆ı ile öğretmen ve öğrenciler bu konulardan haberdar olabilmektedir (Klosterman, Sadler ve Brown, 2012).

Öğrencilerin okuma ve medya okuryazarı olma ile ilgili edindikleri beceriler, SBK ile ilgili nihai karar vermeleri üzerinde büyük etkiye sahiptir. Medyayı doğru anlayan ve yorumlayan bireyler, SBK'nın yer aldığı web siteleri, blogları ve haberleri doğru analiz edebilirler (Dani, Wan ve Henning, 2010). Dikkat edilirse günümüz teknoloji çağında bilgi edinme ihtiyacımız en temel gereksinimlerimizden biri haline gelmişken; özellikle bilgiye ulaşma araçlarından biri olan gazeteler gerek internet gerekse basılı medya aracı olarak hayatımızda önemli yer edinmektedir (Aydın ve Karaçam, 2015). Gazeteler, sosyo-bilimsel içerikleriyle bireylerin ve toplumların düşüncelerini ve kararlarını etkileyebilecek güce sahiptir (Jarman ve McClune, 2003). Bu açıdan bir hayli önemli görülen popüler medya aracı gazeteler artık SBK ve diğer bilimsel konuları keşfetmekte bireylere önemli bir bilgi kaynağı olmaktadırlar (Dimopoulos ve Koulaidis, 2003).

Alanyazında gazetelerin eğitimde kullanımı ile ilgili pek çok çalışma olmakla birlikte (Akcay, Kapici ve Yager, 2017; Bozkurt, 2010; Buluş Kırıkkaya ve Bozkurt, 2012; Ercan, Bozkurt, Kol, Turgut, Öztürk ve Eş, 2012; Ianacone, 2001; Kavak, Tufan ve Demirelli, 2006; Oliveras, Márquez ve Sanmartí, 2011; Rausch, 2004) öğrencilere/öğretmen adaylarına SBK'larla ilgili farkındalık kazandırmada öğretim sürecinde gazetelerin kullanımına ilişkin çalışmaların (Elliot, 2006; Evren Yapıcıoğlu, 2016; Klosterman vd., 2012; Levinson ve Turner, 2001) sınırlı olduğu görülmektedir. SBK'nın tartışıldığı, fen konularının günlük hayatla ilişkilendirildiği ve günlük yaşamın vazgeçilmez unsuru olan gazetelerin; güncel bilgiye en kolay ulaşılabilecek kaynaklardan biri olması, SBK ile ilgili oluşabilecek farklı görüşlerin birlikte değerlendirilmesine ve bireyin ikilemde kaldığı durumda karar verebilmesine imkân sağlaması bakımından ders öğretim materyali olarak etkin bir biçimde kullanılabileceği düşünülmektedir. Geleceğin öğretmenleri olacak ve fen okuryazar bireyler yetiştirmeyi kendilerine hedef edinen öğretmen adaylarının, en önemli yazıı medya kaynaklarından biri olan gazeteleri sınıflara taşıyabilirlerse birçok açıdan olumlu dönütlerinin olacağı düşünülmektedir. Öğrencilerin yazılı medya kaynaklarına eleştirel bakabilmeleri, fen kavramlarını analiz edebilmeleri, gelecekte verilecek kararlarda söz sahibi olabilmeleri yani bilinçli kararlar verebilmeleri ve en önemlisi yaşam boyu öğrenen bireyler olabilmeleri için doğru okuyan, okuduğunu anlayan, ifade edebilen fen okuryazar bireylere ihtiyaç duyulmaktadır. Bu doğrultuda araştırma buglularının benzer çalışmalara yol göstereceği ve SBK'nın sınıf içi uygulamalarında gazatelerin sınıflara taşınacağı düşünülmektedir. 


\subsection{Amaç}

Bu çalışmada fen bilgisi öğretmen adaylarının popüler medyada sıklıkla yer alan fen kavramlarını ve SBK ile ilgili farkındalıklarını tespit etmek/belirlemek amaçlanmaktadır.

\section{YÖNTEM}

Öğretmen adaylarının gazetelerde yer alan SBK ile ilgili farkındalıklarının inceleme konusu yapıldığı bu çalışmada; çalışma grubu, veri toplama aracı, veri toplama süreci ve verilerin analizi boyutlarında nitel araştırma paradigması esas alınmıştır. Bu bölüm ile ilgili alt başlıklar sırası ile aşă̆ıda sunulmuştur:

\section{1 Çalışma Grubu}

Fen bilimleri dersi öğretim programlarının vizyonu olan ve günümüz bilgi çağında tüm bireylerin fen okuryazar olarak yetiştirilmesinde önemli bir bileşen olarak SBK karışımıza çıkmaktadır. SBK'yı öğrencilere tanıtacak ve öğretecek olan öğretmenlerin mesleğe başlamadan önce bu konularla ilgili farkındalık kazanmaları ve bilgi sahibi olmaları önemli görülmektedir. Nitekim çalışma grubu belirlenirken bu durum dikkate alınmış ve uygulama öğretmen adayları ile yürütülmüştür. Bu araştırmanın çalışma grubu, 2016-2017 eğitim-öğretim yılında bir devlet üniversitesinde öğrenim gören ve 3.sınıfa devam eden 15 (13 kadın, 2 erkek) fen bilgisi öğretmen adayından oluşmaktadır. Çalışma grubu amaçlı örnekleme yöntemlerinden uygun örnekleme yöntemine göre belirlenmiştir (Patton, 2014). Çalışma grubunun belirlenmesinde, çalışmanın dersin amaç ve kapsamına uygun "Medya Okuryazarlı̆̆ı" seçmeli dersinde yürütülmesi ve fen bilgisi öğretmen adaylarının bu dersi gönüllülük esası ile seçmeleri önemli görülmüştür. Araştırma sürecine dersi seçen bütün öğretmen adayları katılım göstermiştir.

\subsection{Veri Kaynakları ve Uygulama Süreci}

Uygulama süreci iki aşamadan oluşmaktadır. İlk aşamada, araştırmacılar tarafından 2016 yılına ait gazete tirajları dikkate alınarak en yüksek tiraja sahip 4 ulusal gazete 1 ay boyunca takip edilmiş ve incelenen 120 gazete haber metni arasından fen ile ilgili olan 32 haber metni belirlenmiştir. Veri kaynağı olarak kullanılan haber metinleri, ders saatinin sınırlı olması ve uygulama sürecinin belirlenen zamanda yürütülmesi ve tamamlanması sebebiyle araştırmacılar tarafından daha önceden belirlenmiştir.

Araştırmanın ikinci aşaması ise öğretmen adaylarının aktif katılımı ile planlanmış bir uygulama sürecinden oluşmaktadır. 4 hafta olarak planlanan araştırmada ilk olarak öğretmen adayları ile SBK'nın özelliklerine değinilmeden günlük hayattan örnekler üzerinden sınıf içi tartışma gerçekleştirilmiştir. Sonrasında fen bilimleri dersi öğretim programında yer alan SBK ve sosyobilimsel konular ile fen okuryazarlık ilişsisi tartışılmıştır. Öğretmen adayları daha önce SBK ile ilgili bilgi sahibi değillerdir ve aynı ders döneminde Fizikte Özel Konular/Kimyada Özel konular ve Özel Öğretim Yöntemleri I derslerinde bu konularla ilgili bilgi sahibi olacakları düşünülmektedir. Uygulamanın ikinci haftası öğretmen adayları üçer kişilik beş gruba ayrılmış ve uygulama süreci grup çalışmaları şeklinde devam etmiştir. Gruplar, bir önceki eğitim-öğretim yılı genel akademik not ortalamaları dikkate alınarak heterojen biçimde oluşturulmuştur. Araştırmada gruplar arasındaki iletişim, paylaşım, değerlendirme ve ortak karar alabilme becerileri araştırmacılar tarafından önemsenmiş ve grup içi geçen süreç not edilmiştir. Uygulamanın bu aşamasında her gruba araştırmacılar tarafından seçilen fen ile ilgili haber metinleri verilmiş ve adaylardan öncelikle metinlerde geçen fen kavramlarını tespit etmeleri ve anlamlarını yazılı olarak ifade etmeleri istenmiştir. Öğretmen adaylarına fen kavramlarını bulma ve anlamlarını yazmak için 2 ders saati (90 dakika) verilmiştir. Araştırmanın bu bölümü adayların fen kavramlarını tespit edebilme durumlarını belirlemek ve doğru tanımlama/eksik tanımlama/tanımlayamama şeklinde genel bir öngörü yapmak amacıyla uygulanmıştır. Bu ön uygulama, adayların gazetelerde yer alan fen ile ilgili haber metinlerindeki fen kavramlarını tespit edebilme, okuduğunu anlayıp yorumlayabilme ve kavramlarla ilgili açıklamalarda bulunabilme durumlarının belirlenmesine yönelik bir betimleyici 
özellik de taşımaktadır. Araştırmanın üçüncü haftası ilk ders saatinde gruplara sosyo-bilimsel konuların tanımı ve özelliklerine ilişkin soruların yer aldığı form uygulanmıştır. Formdaki soruların grup olarak cevaplanmasında, uygulama sürecinin grup çalışması biçiminde yürütülmesi ve sorulara cevap verirken grupların kendi içinde tartışmaları ve sosyo-bilimsel konularla ilgili fikir alışverişi yapabilmeleri bakımından önemli görülmüştür. Soru formunda, (i) bilgiye ulaşırken kullanılan kaynaklar (ii) bir bilimel konuyu sosyo-bilimsel yapan özellikler, (iii) bir sosyo-bilimsel konu ile ilgili karar verirken dikkat edilen hususların fen okuryazarlık bağlamında değerlendirilmesi ile ilgili sorular yer almaktadır. Fen bilgisi öğretmen adaylarının formda yer alan soruları 1 ders saati içerisinde ve grup arkadaşları ile birlikte tartışmaları ve görüşlerini yazılı biçimde ifade etmeleri istenmiştir. İkinci ders saatinde ise formdaki sorular üzerine konuşulmuş ve gruplar sırası ile kendi görüşlerini beyan etmişlerdir. Buradaki amaç, öğretmen adaylarının uygulamanın ikinci aşamasına başlamadan önce bilgiye ulaşırken kullandıkları kaynakları, SBK ile ilgili bilgilerini ve medyada yer alan konulardan sosyo-bilimsel olanları diğer konulardan ayırt edebilme/farkında olma durumlarını tespit etmektir. Böylece öğretmen adayları SBK ile ilgili bazı temel özellikleri tasvir edebilmişlerdir. Araştırmanın son haftasında ise gruplar kendilerine verilen haber metinlerinden hangilerinin SBK ile ilgili olduklarını belirlemiş ve belirlemiş oldukları konuları daha önce ifade ettikleri özellikler kapsamında ilişki kurarak değerlendirmeye çalışmışlardır. Mesela, belirlenen SBK ile ilgili olarak araştırmanın bu aşamasında; Tartışmaya açık bir konu mu? Sorunlu/hastalıklı biçimde yapılandııımış, çözüm bekleyen bir konu mu? (Sadler ve Zeidler, 2005a; 2005b) gibi sorulara cevap aranmıştır.

Uygulamanın tüm sürecinde araştırmacılardan biri süreci yürütmüş diğer araştrımacı ise gözlemci olarak alan notları tutmuştur. Alan notları öğretmen adaylarının fen kavramlarını tespit etme, açıklama ve SBK ile ilgili haber metinlerini değerlendirme aşamalarında göstermiş oldukları olumlu/olumsuz tavrı belirlemek ve süreçle ilgili düşüncelerini anlamak ve gözlemlemek amacıyla alınmıştır. Araştırmanın veri kaynağını öğretmen adaylarının belirledikleri fen kavramları, SBK ile ilgili soru formu, haber metinlerinde yer alan SBK'yı tespit edip açıkladıkları gazeteler ile araştırmacıların gözlem ve alan notları oluşturmaktadır.

\subsection{Verilerin Analizi}

Araştrımanın ilk aşamasından elde edilen veriler yani fen bilgisi öğretmen adaylarının gazetelerde yer alan fen kavramlarının ne kadarını tespit etme/edememe frekans değerleri belirlenmiştir. SBK ile ilgili soru formunun iki sorusu (bilgiye ulaşırken kullanılan kaynaklar ve bir sosyo-bilimsel konuyla ilgili karar verirken dikkat edilen hususların fen okuryazarlık bağlamında değerlendirilmesi) içerik analizine tabi tutulmuştur. Analiz sürecinde gruplar yeniden adlandırılmıştır (örneğin Grup 1 için G1, Grup 2 için G2 biçiminde). Elde edilen veriler iki araştırmacı tarafından bağımsız biçimde değerlendirilmiş, analiz edilmiş ve tekrar eden kelime ve cümelelerden yola çıkılarak ortak kod şemaları oluşturulmuştur (Bogden ve Biklen, 2007; Gay, Mills ve Airasian, 2006). İki araştırmacının kod şemaları arasında benzerlik sağlandığında nihai kod listesine ulaşılmıştır. İ̧̧erik analizine tabi tutulan iki soru için kategori, kod ve örnek ifadeler Tablo 1'de sunulmuştur:

Tablo 1. Kategori, Kod ve Örnek ifadeler

\begin{tabular}{lll}
\hline Kategori & Kod & Örnek ifade \\
\hline Medya & Sosyal media & "grup içinde konuştuğumuzda en çok sosyal medyayı \\
& kullanıyoruz tabi ki..." \\
& "TV programlarında birçok konu ile ilgili bilgi sahibi \\
& olabiiriz özellikle tartışma programları..." \\
& &
\end{tabular}

SBK ile ilgili soru formunun bir bilimel konuyu sosyo-bilimsel yapan özelliklerle ilgili sorusunun veri analizinde kodlar daha önceden belli olduğundan dolayı betimsel analiz tekniği kullanılmıştır. Betimsel analiz, elde edilen verilerin daha önceden belirlenmiş temalara göre düzenlenmesi ve yorumlanmasını içeren bir nitel veri analiz türüdür (Yıldırım ve şimşek, 2013). Kodlar şu şekildedir: Bir konunun SBK olabilmesi için sahip olması gereken; toplum içerisinde anlaşmazlıklara yol açan 
(i), tartışmaya açık (ii), bir çözüm bekleyen (iii), birden fazla bakış açısı ile değerlendirilebilen (iv) hakkında kesin sonuca varılamayan (v) ve genel olarak ahlaki ve etik konuları içeren (Sadler ve Zeidler, 2005a; 2005b) özelliklere sahip konular olmaları temel alınmıştır.

\section{BULGULAR}

Araştırma bulguları alt başlıklar biçiminde sırası ile sunulmuştur.

\subsection{Fen Bilgisi Öğretmen Adaylarının Haber Metinlerindeki Fen Kavramlarını Tespit Etme ve Açıklayabilme Durumları}

Araştırma bir grup çalışması olduğundan bu bölümde her gruba ait ve her grubun kendi içinde verilerinin değerlendirilmeye çalışıldığı bulgular sırası ile verilmiştir. Araştırmaya katılan öğretmen adayları grup arkadaşları ile kendilerine verilen 32 haber metninde yer alan 82 fen kavramını tespit etme durumlarına ilişkin bulguları Tablo 2'de sunulmuştur:

Tablo 2. Grupların Fen Kavramlarını Tespit Etme ve Açıklayabilme Durumları

\begin{tabular}{llccccc}
\hline Gruplar & $\begin{array}{l}\text { Fen } \\
\text { Kavramları }\end{array}$ & $\begin{array}{c}\text { Tespit } \\
\text { Edememe }\end{array}$ & $\begin{array}{c}\text { Tespit } \\
\text { etme }\end{array}$ & $\begin{array}{c}\text { Doğru } \\
\text { Açılama }\end{array}$ & $\begin{array}{c}\text { Eksik } \\
\text { Açılama }\end{array}$ & Açıklayamama \\
\hline 1.Grup & & 5 & 77 & 13 & 36 & 28 \\
2.Grup & & 12 & 70 & 17 & 21 & 32 \\
3.Grup & 82 kavram & 5 & 77 & 31 & 25 & 21 \\
4.Grup & & 10 & 72 & 18 & 35 & 19 \\
5.Grup & & 7 & 75 & 10 & 21 & 44 \\
\hline
\end{tabular}

Tablo 2 incelendiğinde, birinci grup ve üçüncü grup 82 fen kavramından 77'sini tespit ederken, 5 kavramı tespit edememiştir. Birinci grupta adayların tespit edilen kavramlarla ilgili olarak çoğu kavramı yanlış açıkladıkları ( $f=36)$, birçoğunu ( $f=28)$ açıklayamadıkları ve bir kısmını $(f=13)$ ise doğru açıkladıkları görülmektedir. Üçüncü grubun ise tespit edilen kavramlardan çoğunu ( $f=31)$ doğru açıkladıkları, birçoğunu $(f=25)$ eksik açıkladıkları ve yine birçoğunu da $(f=21)$ açıklayamadıkları tespit edilmiştir. Ikinci grup, tespit edilen kavramlardan çoğunu ( $f=32)$ açıklayamamış, üçüncü grup kavramların çoğunu $(f=35)$ eksik açıklarken; beşinci grup ise kavramların çoğunu $(f=44)$ açıklayamamıştır.

Frekans değerleri göz önüne alınırsa tüm grupların gazete metinlerine yer alan fen kavramlarını çoğunlukla tespit edebildikleri ancak kavramları açıklamada güçlük çektikleri görülmektedir. Bununla ilgili örnek birkaç grup görüşü şu şekildedir:

Tüm gruplar $(\mathrm{n}=5)$ mikrop ve asit yağmuru fen kavramlarını haber metinlerinden tespit etmişler ve bu kavramlarla ilgili farklı açıklamalarda bulunmuşlardır:

"Hastalanmaya neden olan ve mayalanmaya yol açan mikroskobik canlılardır"(doğru açıklama)(G4)

"Mikroplar hastalık yaparlar" (eksik açıklama) (G3)

"Asit yağmuru kullanılan yakıtların yanmasıyla kükürtdioksitin yağmurla

birlikte yeryüzüne inmesi" (doğru açılkama)(G2)

"Bulutlarda toplanmış zararlı asitlerin yeryüzüne inmesidir asit yağmuru"

(yanlış açıklama)(G1)

"Asit yağmuru her zaman yağabilir" (açıklayamama) (G5)

Araştırmacı alan notlarında da grupların fen kavramlarını tespit etmede kendi aralarında tartıştıkları, birlikte karar vererek hareket ettiklerine ilişkin gözlem notları yer almaktadır. Özellikle öğretmen adaylarının kararlarını alırken ve açıklarken grup içerisinde birbirlerine baktıkları (Sen ne düşünüyorsun? gibi ifadeler kullanmışlardır), birbirlerinin süreçte önerilerini aldıkları (Sence bu açıklama doğru mu? Peki, farklı düşünen var mı? gibi sorular yöneltmişlerdir) belirlenmiştir. 
Araştırmacı öğretmen adaylarının daha çok günlük hayatta duydukları mesela atmosfer, nükleer gibi kavramları tespit etmede ve açıklamada zorlanmadıklarını gözlemlemiştir. Yukarıda belirtilen örnek ifadelerden G1 asit yağmurunu tespit edebildiği halde yanlış açıklama yapmıştır. Öğretmen adayları grup içerisinde de benzer fikir birliğine vararak bu bulguya ulaşmışlardır. G5 ise asit yağmuru kavramını tespit edebildiği halde açıklayamamıştır. Fen kavramlarını açıklama aşamasında grup içerisinde de "Aslında her zaman duyduğumuz bir şey ama nassı açıklasak..." biçiminde kendi aralarında konuştukları gözlemlenmiştir.

\subsection{Fen Bilgisi Öğretmen Adaylarının Bilgiye Ulaşırken Kullandıkları Kaynaklar ve SBK ile ilgili Genel Bilgileri}

Tablo 3. Grupların Bilgiye Ulaşırken Kullandıkları Kaynaklar

\begin{tabular}{lll}
\hline Kategori & Kod & $\mathrm{f}$ \\
\hline Internet & Internet & 5 \\
\hline \multirow{2}{*}{ Medya } & Sosyal medya & 5 \\
& TV & 4 \\
& Gazete & 3 \\
\hline Otorite & Uzman & 3 \\
\hline \multirow{2}{*}{ Çevre } & Arkadaş & 2 \\
& Aile & 2 \\
\hline
\end{tabular}

Tablo 3'te görüldüğü üzere, araştrımaya katılan bütün grupların internet $(f=5)$ ve medya $(f=5)$ araçlarını kullandıkları belirlenmiştir. Bilgi kaynağı olarak 3 grup uzman görüşlerine başvurduklarını, 2 grup ise çevrelerinden arkadaş ve ailelerinden de bilgi edindiklerini belirtmişlerdir.

"grup içinde konuştuğumuzda en çok interneti kullanıyoruz tabi ki..."(G3)

“...elimizde her zaman telefonlarımız olduğundan medya araçlarını sık kullanıyoruz. Özellikle sosyal medya hayatımızın parçası olmuş durumda. Grup olarak biribirimize sorduğumuzda gazete alan yok ama internetten gazete haberlerini takip ediyoruz. " (G4)

ifadelerinden anlaşılacağı üzere grupların bilgi kaynağı olarak internet ve medya kaynakları vurgusu yaptıkları görülmektedir. Uzman görüşüne başvurulması gerektiğini ifade eden G2'nin görüşü şu şekildedir:

"Bir konuyu araştırırken kimin söylediği bizim için önemli. Yani düşünsenize o kişi o alanda uzmansa nilgi almak istersiniz. Biz böyle düşünüyoruz. Tabi çoğunlukla internete başvuruyoruz..."(G2)

Bilgi kaynağı olarak çevreyi de önemli gördüklerini belriten G4'ün görüşü şu şekildedir:

"Kim çevresinden etkilenmez ki? Biz bile birbirimize birşeyler söylediğimizde bilmediğimiz şeyleri arkadaşımızdan öğrenebiliyoruz..."(G4)

Grupların kendilerine verilen bir konuyu sosyo-bilimsel konu yapan özelliklere ilişkin görüşleri Tablo 4'te sunulmuştur: 
Tablo 4. Grupların SBK'ya İlişkin Görüşleri

\begin{tabular}{lccccc}
\hline SBK Özellikleri & 1.Grup & 2.Grup & 3.Grup & 4.Grup & 5.Grup \\
\hline Toplum içerisinde anlaşmazlıklara yol açan & $\sqrt{ }$ & - & $\sqrt{ }$ & $\sqrt{ }$ & $\sqrt{ }$ \\
Tartışmaya açık & $\sqrt{ }$ & $\sqrt{ }$ & $\sqrt{ }$ & $\sqrt{ }$ & $\sqrt{ }$ \\
$\begin{array}{l}\text { Çözülmeyi bekleyen } \\
\text { Birden fazla bakış açısı ile }\end{array}$ & - & - & - & $\sqrt{ }$ & $\sqrt{ }$ \\
değerlendirilebilen & $\sqrt{ }$ & $\sqrt{ }$ & $\sqrt{ }$ & - & $\sqrt{ }$ \\
$\begin{array}{l}\text { Hakkında basit biçimde sonuca } \\
\text { varılamayan }\end{array}$ & $\sqrt{ }$ & - & $\sqrt{ }$ & $\sqrt{ }$ & - \\
Genel olarak ahlaki ve etik konuları içeren & - & $\sqrt{ }$ & - & - & - \\
\hline
\end{tabular}

Tablo 4 incelendiğinde grupların çoğunun SBK ile ilgili, bu konuların tartışmaya açık ( $f=5$ ), toplum içerisinde anlaşmazlıklara yol açan ( $f=4)$, birden fazla bakış açısı ile değerlendirilebilen $(f=4)$ ve hakkında basit biçimde sonuca varılamayan $(f=3)$ özellikler üzerinde durdukları görülmektedir. Özellikle 1.2.3. ve 4. grupların SBK ile ilgili çoğu özelliğe değindikleri, 2. grubun ise daha sınırlı bir yaklaşım içinde oldukları belirlenmiştir. SBK'ların ahlaki ve etik konuları içermesine yönelik olarak ise sadece 2.grup görüş bildirmiştir. 2.grup öğretmen adaylarından birisi diğer arkadaşlarına “...arkadaşlar organ bağışını düşünün aslında karar verirken sanki dini yönü de etkili olabiliyor." şeklinde görüş bildirmiş bir diğer grup da "Doğru organ bağışında birden fazla görüş olabilir ki dediğin gibi ahlaki açıdan da değerlendirilebilir." biçiminde görüşünü ifade etmiştir.

SBK'nın özelliklerini belirten gruplar bir sosyo-bilimsel konu ile ilgili karar verirken hangi ölçütleri dikkate aldıklarını fen okuryazarlık bağlamında değerlendirmiş ve görüşlerine ilişkin frekans değerleri Tablo 5'te gösterilmiştir:

Tablo 5. Grupların Karar Ölçütleri

\begin{tabular}{lll}
\hline Kategori & Kod & $f$ \\
\hline Bilimsel kaynak & Makale & 4 \\
& Kitap & 4 \\
& Tez & 2
\end{tabular}

Tablo 5'te görüldüğü üzere araştrımaya katılan grupların çoğunun bir sosyo-bilimsel konu ile ilgili karar verirken bilimsel kaynaklara sırası ile makale $(f=4)$, kitap $(f=4)$ ve tez $(f=2)$ çalışmalarına başvurdukları belirlenmiştir. Birden fazla kaynağa başvurmanın karar vermede önemli ölçüt olduğunu ifade eden G3 ve G4'ün görüşleri şu şekildedir:

"Bu konular zaten kafa karıştırıı. O nedenle biz grup olarak konu ile ilgili yazılmış farkı makalelerden araştırma, sorgulama yapmanın önemli olduğunu düşünüyoruz. Yoksa herkes herşeyi konuşabiliyor..." (G3)

"Biz bir konuda karar vermeden önce yapılmış çalışmalarda uzmanlar neler söylemişler bunları sorgulamamı gerektiğini düşünüyoruz. O zaman daha iyi sorgulayabilir ve karar verebiliriz sanki. Çünkü birbirinden farklı düşünen insanlar olabilir..."(G4)

\subsection{Fen Bilgisi Öğretmen Adaylarının Gazete Haberlerinde SBK'yı Tespit Etme Durumları}

Araştırmanın son aşamasında gruplar, SBK ile ilgili özellikleri betimlemelerinin ardından kendilerine verilen gazete haberlerinden SBK olanları tespit etmeye çalışmışlardır. Bununla ilgili olarak haber metinlerinde yer alan ve gruplar tarafından belirlenen SBK Tablo 6'da yer almaktadır. 
Tablo 6. Grupların Haber Metinlerinde Belirledikleri SBK

\begin{tabular}{|c|c|c|c|c|c|c|c|c|c|c|c|c|c|}
\hline Gruplar & $\begin{array}{l}\frac{\varepsilon}{0} \\
\frac{0}{d} \\
\frac{0}{0} \\
\frac{d}{d} \\
\frac{d}{2} \\
\frac{\partial}{3}\end{array}$ & 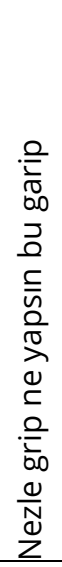 & 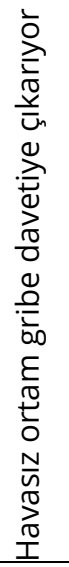 & 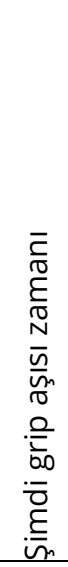 & 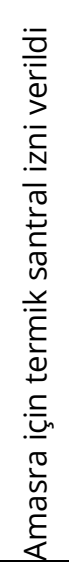 & 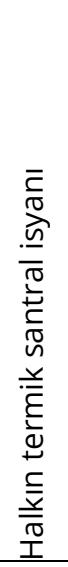 & 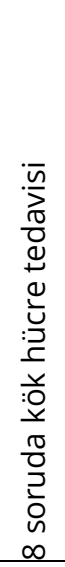 & 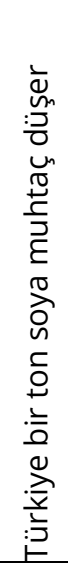 & 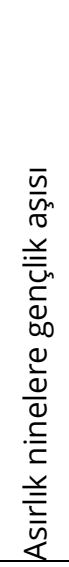 & 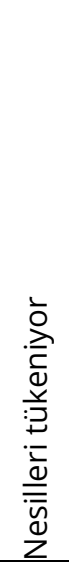 & 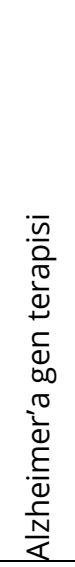 & 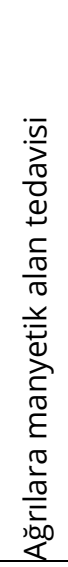 & $\begin{array}{l}\varepsilon \\
\frac{\varepsilon}{0} \\
0 \\
\end{array}$ \\
\hline 1.Grup & $\sqrt{ }$ & $\sqrt{ }$ & $\sqrt{ }$ & $\sqrt{ }$ & $\sqrt{ }$ & $\sqrt{ }$ & $\sqrt{ }$ & $\sqrt{ }$ & - & $\sqrt{ }$ & $\sqrt{ }$ & $\sqrt{ }$ & 11 \\
\hline 2.Grup & $\sqrt{ }$ & $\sqrt{ }$ & $\sqrt{ }$ & $\sqrt{ }$ & - & - & $\sqrt{ }$ & - & - & - & - & - & 5 \\
\hline 3.Grup & $\sqrt{ }$ & $\sqrt{ }$ & $\sqrt{ }$ & $\sqrt{ }$ & $\sqrt{ }$ & $\sqrt{ }$ & - & $\sqrt{ }$ & $\sqrt{ }$ & $\sqrt{ }$ & $\sqrt{ }$ & - & 10 \\
\hline 4.Grup & $\sqrt{ }$ & $\sqrt{ }$ & $\sqrt{ }$ & $\sqrt{ }$ & $\sqrt{ }$ & $\sqrt{ }$ & $\sqrt{ }$ & $\sqrt{ }$ & $\sqrt{ }$ & - & - & $\sqrt{ }$ & 10 \\
\hline 5.Grup & $\sqrt{ }$ & $\sqrt{ }$ & $\sqrt{ }$ & $\sqrt{ }$ & $\sqrt{ }$ & $\sqrt{ }$ & $\sqrt{ }$ & - & - & - & - & - & 7 \\
\hline
\end{tabular}

Tablo 6'da görüldüğü üzere her SBK en az bir grup tarafından tespit edilmiştir. Özellikle "Nükleere devam", "Şimdi grip aşısı zamanı", "Nezle grip ne yapsın bu garip" ve "Havasız ortam gribe davetiye çıkarıyor" başlıklı haber metinlerini tüm grupların $(n=5)$ tespit edebildikleri görülmektedir. Bu bulgudan hareketle grip aşısı konusunun hava değişimi ile birlikte gündemde yer alması ve nükleer santral kurulmasının ise (özellikle de Sinop ve Mersin illerimiz için) uzun zamandır gündemi meşgul etmesi gibi etmenler bu bulgunun elde edilmesine neden olabilir. Dikkat edilirse 32 haber metni arasından 12 haber metni SBK ile ilgilidir. Haber metinleri arasından en fazla ( $f=11)$ SBK içerikli haber metnini 1. grup tespit etmiştir. Uygulamanın ilk basamağında da haber metinlerinde yer alan fen kavramlarını en fazla ( $f=77$ ) tespit eden gruplardan biri olan 1.grubun kavramları doğru açıklama frekans değeri düşük olmasına rağmen $(f=13)$ adaylar, SBK'ı tespit edebilmiş ve açıklayabilmişlerdir. Bununla ilgili olarak 1. grubun SBK olarak düşündükleri haber metinleri ve ifadeleri dikkate alındığında mesela Grip aşısı sosyo-bilimsel konusu ile ilgili olarak görüşü şu şekildedir: 


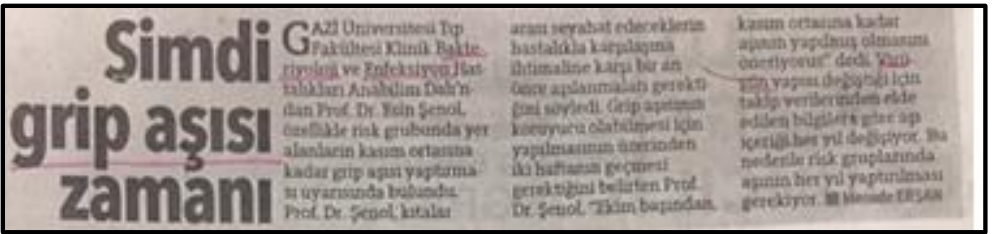

"...Yakın zamanda gündeme gelip haberlerde çok yer etmiştir. Şu anda da sonbaharda olduğumuz için aşının hem zararları hem yararları göz önüne alınarak aşı olunmalı mı olunmamalı mı konusunda halen net bir fikre sahip olmadığımız için dikkatimizi çekti. Çünkü bu konu çok tartışılıyor, biz bile grup içinde tartıştık mesela. Birimiz yaptırııı derken ikimiz yaptırmayız dedik. Bu şekilde kişiler arasında bir sonuca varılmadı̆̆ını düşündüğümüz için bu haber metnini SBK olarak aldık." (G1)

Tablo 4'te grupların SBK ile ilgili görüşleri incelendiğinde 1.grubun SBK'nın özellikleriyle ilgili belirlemiş oldukları ifadeleri SBK içerikli haber metinlerini belirlemede kullandıkları ve değerlendirmelerini de o çerçevede yaptıkları görülmektedir. Yine aynı konuya ilişkin 2. grubun örnek ifadesi şu şekildedir:

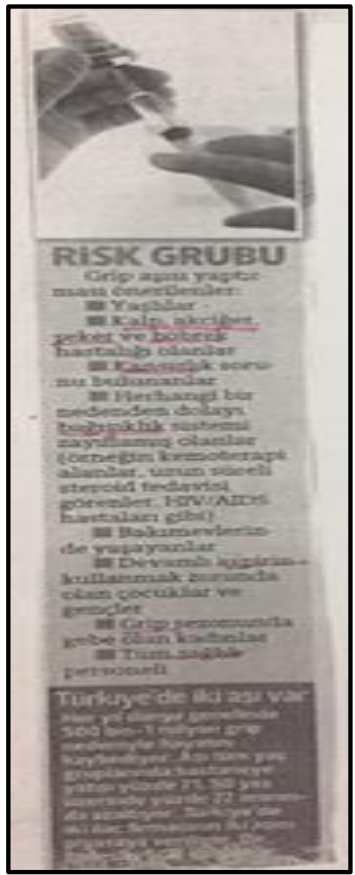

"Grip aşısı her sonbaharda gündeme geliyor. Örneğin hastanelerde bile yaptırın şeklinde reklamlar görüyoruz. Yani toplumun tam olarak karar verilebileceği bir konu değil gibi görünüyor hatta bizim de. Bir de haberde sanki riskli grup yaptırmazsa ölecek gibi yazılmış ne kadar doğru bilemedik. Kendimiz de tartıştık hatta neye göre karar vermeli diye. Bununla ilgili herkes bir şey söylüyor. 0 yüzden şu haber daha doğrudur diyemiyoruz..."(G2)

Haber metinlerinden en az SBK belirleyebilen $(f=5)$ 2. grubun SBK'ya ilişkin teoride tartışmaya açık ve birden fazla bakış açısı ile değerlendirilebilen özelliklerine vurgu yaptıkları ancak haber metinlerinde ise toplum içerisinde anlaşmazlıklara yol açan ve hakkında basit bir biçimde sonuca varılamayan şeklinde özelliklere de dikkat çekerek haber metinlerini belirledikleri belirlenmiştir.

Tablo 6 incelendiğinde 3. ve 4.grubun haber metinlerinden çoğunu $(f=10)$ tespit edebildikleri görülmektedir. Haber metinlerinde geçen fen kavramından hemen hemen tümünü tespit edebilen $(f=77)$ ve diğer gruplara nazaran kavramların çoğunu doğru açıklayabilen $(f=31)$ 3. grubun belirlemiş oldukları SBK'yı seçme gerekçelerine bakıldığında mesela Termik Santral konusuna ilişkin grubun ifadesi şu şekildedir:

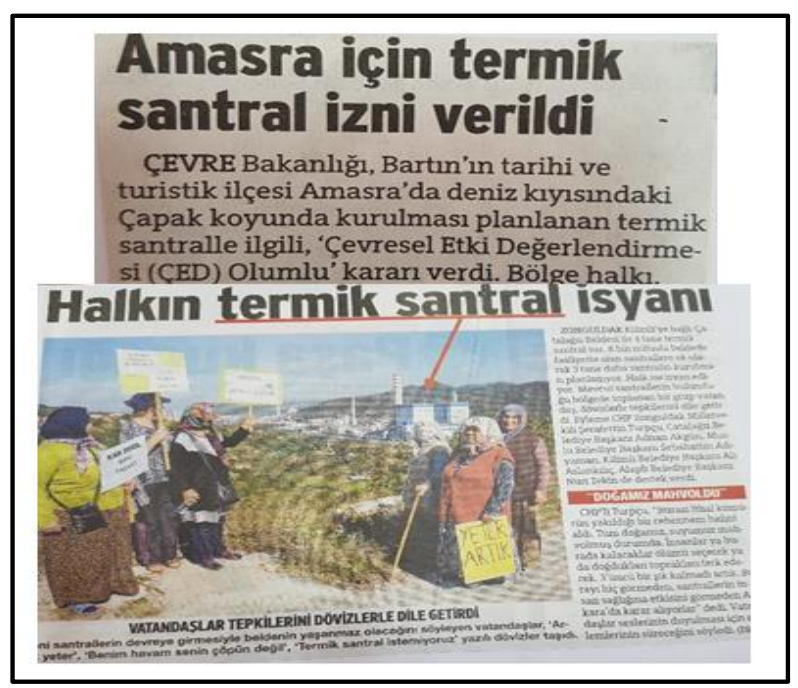

“...Aslında birçok enerjiye göre daha ılımlı gibi duruyor ama yine da tartışmalı bir konu diye düşündük. Grup içinde iki arkadaşımız Amasra'yı görmüş mesela doğanın mahvolmasını istemiyor ama nükleer enerjiden daha masum diye de düşünüyoruz. Farklı görüşler oluştu grupta, zaten gazete haberleri de birbirinden farklı şeyler söylüyor. Bu konu kesin SBK. Kurulmalı mı kurulmamalı kesin bir şey söylense de halk bilinçlense." (G3) 
Haber metinlerine dikkat edilirse termik santral ile ilgili farklı iki görüşü yansıttıkları ve adayların da bu durumdan yola çıkarak konuyu kendi içlerinde tartıştıkları ve konunun çözülmesi yönünde görüş bildirdikleri görülmektedir. Yine Tablo 4'te SBK ile ilgili tasvir ettikleri özellikler dışında uygulama sürecinde çözülmeyi bekleyen ve birden fazla bakış açısı ile değerlendirilebilen özelliklere de vurgu yaptıkları belirlenmiştir. Aynı konu ile ilgili yine benzer görüş 4.gruptan gelmiştir:

"ilk habere bakılırsa Çevre Bakanlığı onaylıyor ama sanki diğer haberde de halk karşı. Zaten bunu görünce dedik farklı görüşler var bu konuda. Tam da SBK özelliklerine uygun bir konu gerçekten. Birincisi tartışmalı zaten biz ile tartıştık mesela çevre bakanlığı onay veriyorsa iyi bir şey gibi geliyor ama sanki doğaya da zararı var. Farklı bakış açılarını yansıtıyor daha görmek lazım sanki. Bu konu SBK olduğuna karar verdik..."(G4)

Tablo 4 incelendiğinde SBK ile ilgili özelliklerin çoğunu ifade eden grubun haber metni üzerinden SBK'nın farklı bakış açılarını yansıtmasına ilişkin vurgusu da dikkat çekmektedir. Aynı haber metni üzerinde her iki grubun da kendi içlerinde de konuyu tartıştıkları ve farklı görüşlerin oluşmasına neden olan özellikleri üzerine gerekçe sundukları görülmektedir. Haber metinlerinin yarıdan fazlasını $(f=6)$ tespit eden 5 . grubun SBK'nın özelliklerine ilişkin ifadelerinin yanı sıra haber metni üzerinden farklı özelliklere de değinmişlerdir. Mesela Nükleer konusu ile ilgili grup görüşü şu şekildedir:

"Tartışmaya açık bir konu. Bulunduğumuz ilde yapılması söz konusu. Halkın da bu konu ile ilgili farklı fikirleri var. Hatta televizyonlarda da çok tartışılıyor. Gazetedeki haberde de dikkatimizi çekti kafamızı karıştıracak şekilde yazılmıştı ve bu nedenle bu konunun sosyo-bilimsel bir konu olduğunu düşünüyoruz. Bakılırsa bakan da onaylıyor ama kafamızda soru işaretleri de var. Sonuçta o kadar insanın sağ/ığını da düşünmek gerekir. Daha kendimiz net karar veremedik. Seçmemizin nedeni ise, daha önce bu konu hakkında bir dersimizde araştırma yapmıştık. Konu ile ilgili az çok bilgimiz vardı ama sosyo-bilimsel olduğunu yeni anladık." (G5)

Nükleer konusu ile ilgili olarak tartışmalı ve hakkında basit bir biçimde sonuca varılamayan şeklinde değerlendirme yapan grupla ilgili bir diğer önemli bulgu ise grup üyelerinin Tablo 4'te belirttikleri SBK'ya ilişkin özelliklerde etik ve ahlak vurgusu

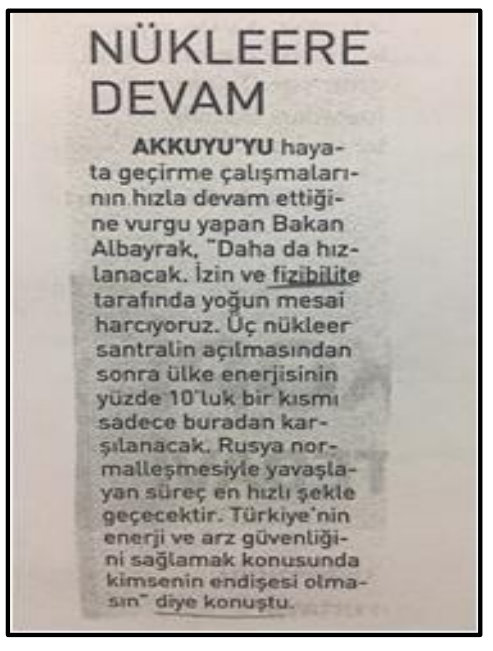
yapmadıkları ancak nükleer konusunda insan sağlığına değinerek, sorumluluk bilinci anlayışına vurgu yaparak dolaylı biçimde bu özelliğe değindikleri tespit edilmiştir. Bütün bulgular göz önüne alınırsa tüm grupların SBK'nın tartışmaya açık olması ve anlaşmazlıklara yol açması özellikleri üzerinde daha çok durdukları hatta çoğunlukla SBK'nın etik ve ahlaki konuları içeren özelliklerine de teorikte değinmedikleri ancak uygulama esnasında bir grubun bu özelliğe dolaylı yoldan gönderme yaptığı belirlenmiştir.

\section{SONUÇ, TARTIŞMA VE ÖNERILER}

Araştırma bulguları incelendiğinde araştırmaya katılan fen bilgisi öğretmen adaylarının oluşturdukları grupların çoğunun 32 haber metninde yer alan fen kavramlarını belirleyebildikleri belirlemiş oldukları fen kavramlarının anlamlarını doğru açıkladıkları, eksik açıkladıkları ya da açıklayamadıkları belirlenmiştir. Kavramları doğru açıklayan gruplardan frekans değeri en yüksek 3. grup iken, eksik açıklamada 1. ve 4. gruplar; kavramların çoğunu açıklayamayan grup ise 5. grup olarak belirlenmiştir. Tüm grupların kavramları tespit edebilmeleri önemli bir bulgu iken; kavramları açıklayabilme durumları dikkat çeken bir başka bulgu olarak karşımıza çıkmaktadır. Grupların fen kavramlarını açıklayabilme durumları farklıık göstermektedir. Araştırmada öğretmen 
adaylarının fen kavramlarına aşina oldukları ancak açıklamakta zorlandıkları görülmektedir. Bu durum da yeterli bilgilerinin olmamasına yorulabilir. Yapılan birçok çalışma, mevcut araştırma sonuçlarını destekler nitelikte gerek öğretmen adaylarının gerekse de öğretmenlerin kavramsal bilgileri ile ilgili yetersizliğine vurgu yapmaktadır (Eş, 2014; Mutlu ve Özel, 2008, Uşak, 2005). Zira bilindiği üzere kavramların tam ve doğru olarak anlamadan anlamlı öğrenme gerçekleșmesini beklemek zordur (Sigler ve Saam, 2006; Snowman ve Biehler, 2003). Eş (2014), öğretmen adaylarının fen kavramlarını tanıdıklarını/bildiklerini ancak kavramların ne anlama geldiği ile ilgili yeterli bilimsel bilgiye sahip olmadıklarını belirtmektedir. Benzer şekilde araştırmada adayların gazete metinlerinde yer alan kavramları tanımlayamamalarının nedeni olarak kavramlarla ilgili bilgi düzeylerinin yeterli olmaması gösterilebilir.

Araştırma sürecinde kullanılan haber metinlerinin fen programlarının daha çok fen-teknolojitoplum-çevre öğrenme alanına hitap etmekte ve toplumu ilgilendiren günlük yaşamdan kesitleri içerdiği görülmektedir. Mesela; öğretmen adaylarının ağaç, atmosfer, bitki, kalp, akciğer, metal ve uzay gibi pek çok kavramı günlük hayatlarında duyduklarına ilişkin konuşmaları araştırmacıların alan notlarında yer almaktadır. Literatürde de benzer biçimde gazetelerde yer alan fen ile ilgili haberlerin varlığı öğrencinin ilgisini çekmekte ve gazetelerin sınıf ortamına getirilmesi ve kullanılmasının fen ile günlük yaşam arasında bir bağ kurabilme anlamında kolaylık sağlayacağı vurgusu yapılmaktadır (Buluş Kırıkkaya ve Bozkurt, 2012; Shibley, 2003). Bu doğrultuda öğrencilerin fen-teknoloji-toplum-çevre bileşenlerini dikkate alarak bu bileşenlerin birbirleri ile ilişkisini günlük hayat bağlamında ortaya koyacakları çeşitli sınıf içi etkinlikler (videolar, senaryolar, bilimsel dergiler gibi) yapılabilir. Farklı öğretim yöntem ve teknikler kullanılarak öğrenciler kavram öğrenmeye teşvik edilebilir ve bu şekilde öğrencilerin kendi bakış açılarını geliştirmelerine yardımcı olunabilir (De Vries, 2005). Bilindiği üzere, fen-teknoloji-toplum ve çevre öğrenme alanında yer alan konular hakkında medya önemli bir bilgi kaynağı olarak kendini göstermektedir (Huang ve Yore, 2003). Bu nedenledir ki medyanın bizlere sunduğu haberleri doğru anlamanın ve yorumlamanın yolunun fen kavramlarını bilmek ve doğru tanımlayabilmek/açıklayabilmekten geçtiği söylenebilir. Nitekim basılı medya aracı olan gazeteler bilim ve teknoloji için önemli bir kaynak olup, çoğu insan için bilimin gerçeği sadece gazete de okuduğundan ibaret olabilmektedir (Levinson ve Turner, 2001). Bu nedenle gazetelerin sınıflarda da bir öğretim materyali olarak kullanılması önerilebilir (McClune ve Jarman, 2010; Rennie, 2007; Wellington ve Osborne, 2001). Tüm bu bilgiler ışı̆̆ında fen kavramlarını doğru tanımlamak ve anlamak için çeşitli sınıf içi uygulamalara yer verilebilir. Öğrencilerin fen kavramlarına aşina olmaları için onlara gazeteler hazırlatılarak kavramları öğrenmeleri sağlanabilir. Gazetelerden öğretim materyali olarak sadece fen derslerinde değil diğer tüm derslerde de yararlanılabilir.

Araştırmada, öğretmen adaylarının bilgi kaynağı olarak çoğunlukla internet ve medya kaynaklarını kullandıkları sonra sırası ile uzman ve çevre ölçütlerini dikkate aldıkları belirlenmiştir. İnternet ve medya kaynakları bilgiye ulaşma, bilgi paylaşma, görüşleri ifade etme gibi birçok fırsat sunmasından dolayı bilgiye ulaşmada sıklıkla tercih edilmektedir (Muntinga, Moorman ve Smith, 2011). Araştırma bulguları incelendiğinde öğretmen adaylarının genellikle SBK ile ilgili olarak, tartışmaya açık, toplum içerisinde anlaşmazlıklara yol açan, birden fazla bakış açısı ile değerlendirilebilen ve hakkında basit biçimde sonuca varılamayan özellikler taşıdığı yönünde görüş bildirdikleri tespit edilmiştir. Alanyazında da araştırmacıların benzer özellikler çerçevesinde SBK'yı tanımladıkları görülmektedir (Kolstø, 2001a; Nielsen, 2012; Topçu, 2015; Sadler, 2004a; Sadler ve Zeidler, 2004; Sadler ve diğerleri, 2006; Walker ve Zeidler, 2007). Grupların verdikleri cevaplarda dikkat çeken bulgu SBK ile ilgili çoğunlukla etik ve ahlaki kavramlarını kullanmamış olmalarıdır. Ancak uygulama esnasında haber metinleri üzerinden SBK ile ilgili farklı özelliklere de değindikleri hatta sadece bir grubun etik ve ahlaki konuları içeren özelliğine değindikleri belirlenmiştir. Araştırmada tüm gruplar haber metinleri arasından özellikle gündemde olan ve popüler medyanın da üzerinde durduğu nükleer, termik santraller ve grip aşısı konularını belirlemişlerdir. Bu durum gazetelerde yer alan SBK içerikli haber metinlerinin güncel, günlük yaşama hitap eden ve genelde adayların aşina oldukları kavramlar içermesinden kaynaklanan bir durum olduğu şeklinde 
yorumlanabilir. Öğretmen adaylarının bir sosyo-bilimsel konu ile ilgili karar verirken birden fazla kaynağa başvurma, farklı görüşleri dinleme, tartışma ortamında bulunma ve konuyu/sorunu benimseme şeklinde ölçütler belirtmişlerdir. Bu ölçütleri açıklarken dolaylı yoldan fen okuryazarlık vurgusu yaptıkları belirlenmiştir. Birçok araştırmacı SBK ile ilgili karar vermede fen okurayzarlığın önemli bir bağlam olduğuna dikkat çekmektedir (Lee, 2007; Sadler, 2004b; Zeidler vd., 2005). Öğrencileri yetiştirecek ve bu konularla ilgili farkındalık oluşturacak öğretmenlerin, öğretmenlik mesleğine başlamadan önce günlük yaşam ile bağ kurarak toplumda yer alan SBK ile ilgili farkındalık kazanmaları ve günlük hayatımızın vazgeçilmez unsuru olan medya araçlarını (gazete, dergi, internet...) doğru anlama, yorumlama ve farklı bakış açılarını değerlendirerek nihai karara varabilmeleri önem arz etmektedir.

\section{Kaynakça}

Akcay, H., Kapici, H. O. ve Yager, R. E. (2017). Using newspapers and advertisement as a focus for science teaching and learning, Universal Journal of Educational Research, 5(1), 99-103.

Aydın, F. ve Karaçam, S. (2015). Öğretmen adaylarının teknolojinin doğasına yönelik görüşlerinin gelişiminde gazete haberlerinin kullanımı. Eğitim Bilimleri Dergisi, 41, 1-17.

Bogden, R. C. ve Biklen, S. K. (2007). Qualitative research for education: An introduction to theories and methods. Boston: Allyn and Bacon. doi: 10.1002/sce.10063.

Bozkurt, E. (2010). ilköğretim 5.Sınıf Fen ve Teknoloji Dersi "Maddenin Değişimi ve Tanınması" Ünitesinde Gazetelerden Yararlanılarak Hazırlanan Ders Etkinliklerinin Tutum, Başarı ve Eleştirel Düşünme Becerilerine Etkisi.Yayımlanmamış Yüksek lisans tezi). Kocaeli Üniversitesi, Kocaeli.

Buluş Kırıkkaya, E. ve Bozkurt, E. (2012). Fen ve teknoloji derslerinde gazetelerden yararlanılarak hazırlanan ders etkinliklerinin öğrencilerin akademik başarısına etkisi. Eğitim ve Bilim, 37(165), 1-17.

Chang Rundgren, S. N. ve Rundgren, C. J. (2010). SEE-SEP: From a separate to a holistic view of socioscientific issues. Asia-Pacific Forum on Science Learning \& Teaching, (11).

Cooper, C. B. (2011), Media literacy as a key strategy toward improving public acceptance of climate change science. Bioscience, 61, 231-237.

Dani, D., Wan, G. ve Henning, J. E. (2010). A case for media literacy in the context of socioscientific issues. New Horizons in Education, 58(3), 85-98.

De Vries, M. J. (2005). Teaching about technology: An introduction to the philosophy of technology for non-philosophers. Science \& Technology Education Library, 27, Published by Springer.

Dimopoulos, K. ve Smyrnaiou, Z. (2005). Factors related to students' interest in science learning. In D. Koliopoulos \& A. Vavouraki (Eds.), Science Education at Cross Roads: Meeting the Challenges of the 21st Century (pp. 135-142). Athens: Association for Science Education.

Driver, R., Newton, P. ve Osborne, J. (2000). Establishing the norms of scientific argumentation in classrooms. Science Education. 84, 287-312.

Elliott, P. (2006). Reviewing newspaper articles as a technique for enhancing the scientific literacy of student-teachers. International Journal of Science Education, 28, 1245-1265.

Ercan, S., Bozkurt, E., Kol, A.A., Turgut, H., Öztürk, N. ve Eş, H. (2012-Eylül). Öğretmen adaylarının fen okuryazarlıkları: Anahtar fen kavramları boyutu. 21. Ulusal Eğitim Bilimleri Kongresi, Marmara Üniversitesi, İstanbul.

Eş, H. (2014). Concepts of Vegetable and Fruit in Preschool and Elementary Education. Journal of Baltic Science Education, 13(5), 709-725. 
Evren Yapıcoğlu, A. (2016). Fen bilimleri öğretmen adaylarının sosyobilimsel durum temelli öğretim yaklaşımı uygulamalarına yönelik görüşleri ve çalışmalarına yansıtmaları. Hacettepe Üniversitesi Eğitim Bilimleri Enstitüsü Eğitim Araştırmaları Dergisi, 2(2), 132-151.

Fleming, R. (1986). Adolescent reasoning in socio-scientific issues. Part I: Social cognition. Journal of Research in Science Teaching, 23, 677-687.

Gay, L. R., Mills, G. E. ve Airasian, R. (2006). Educational research: Competencies for analysis and applications. Upper Saddle River, NJ: Pearson/Merrill/Prentice Hall.

Huang, H. P. ve Yore, L. D. (2003). A comparative study of Canadian and Taiwanese grade 5 children's environmental behaviours, attitudes, concerns, emotional dispositions, and knowledge. International Journal of Science and Mathematics Education, 1, 419-448.

Ianacone, J. A. (2001). I only know what I read in the paper. English Journal, 82(8), 46-49.

Jarman, R. ve McClune, B. (2001). Use the news: a study of secondary teachers' use of newspapers in the science classroom. Journal of Biological Education, 35(2), 69- 74.

Kavak, N., Tufan, Y. ve Demirelli, H. (2006). Fen-teknoloji okuryazarlığı ve informal fen eğitimi: gazetelerin potansiyel rolü. Gazi Üniversitesi Eğitim Fakültesi Dergisi, 26(3), 17-28.

Klosterman, M. L., Sadler, T. D. ve Brown, J. (2012). Science teachers' use of mass media to address socio-scientific and sustainability issues. Research in Science Education, 42, 51-74.

Kolstø, S. D. (2001a). To trust or not to trust, pupils' ways of judging information encountered in a socio-scientific issue. International Journal of Science Education, 23, 877-901.

Kolstø, S. D. (2001b). Scientific literacy for citizenship: Tools for dealing with the science dimension of controversial socioscientific issues. Science Education, 85, 291-310.

Levinson, R. ve Turner, S. (2001). Valuable lessons: Engaging with the social context of science in schools. London, UK: The Wellcome Trust.

McClune, B. ve Jarman, R. (2010). Critical reading of science-based news reports: Establishing a knowledge, skills and attitudes framework. International Journal of Science Education, 32, 727 752.

MEB (2006). Illköğretim fen ve teknoloji dersi (6, 7 ve 8. sınıflar) öğretim programı. Ankara: Talim ve Terbiye Kurulu Başkanlığı.

MEB (2013). ilköğretim fen bilimleri dersi (3. - 8. sınıflar) öğretim programı. Ankara: Talim ve Terbiye Kurulu Başkanlı̆̆ı.

MEB (2018). Fen bilimleri dersi öğretim programı (ilkokul ve Ortaokul 3, 4, 5, 6, 7 ve 8. Sınıflar). Ankara: Talim ve Terbiye Kurulu Başkanlığı.

Miller, J. D. (1998), The measurement of civic scientific literacy. Public Understanding of Science, 7, 203-223.

Muntinga, D. G., M. Moorman ve E.G. Smit. 2011. Introducting COBRAs: Exploring motivations for brand-related social media use. International Journal of Advertising 30(1), 13-46.

Mutlu, M. ve Özel, M. (2008). Sınıf öğretmen adaylarının çiçekli bitkilerin büyüme ve gelişimi konuları ile ilgili anlama düzeyleri ve kavram yanılgıları. [Preservice elementary teachers' understanding levels and misconceptions related to the grow and development of flowering plants]. Kastamonu Eğitim Dergisi, 16(1), 107-124.

Nielsen, J. A. (2012). Arguing from Nature: The role of 'nature' in students' argumentations on a socio-scientific issue. International Journal of Science Education, 34(5), 723-744.

National Research Council [NRC]. (1996). National science education standards. Washington DC: National Academies Press.

Oliveras, B., Márquez, C. ve Sanmartí, N. (2011). The use of newspaper articles as a tool to develop critical thinking in science classes. International Journal of Science Education, 35(6), 1-21. 
Öztürk, N., Eş, H. ve Turgut, H. (2017). How gifted students reach decisions in socio-scientific Issues? Warrants, Information sources and role of media, International Online Journal of Educational Sciences, 9(4), 1111 -1124.

Patton, M. Q. (2014). Nitel araştırma tasarımı. B. Tarman ve M.F. Yiğit, (Çev.), M. Bütün, S. B. Demir (Çev. Ed.), Nitel araştırma ve değerlendirme yöntemleri (s. 209-258) içinde. Ankara: PegemA.

Rausch, A. S. (2004). Newspaper in education' in rural Japan. Journal of Asian Pacific Communication, $14(2), 223-244$.

Rennie, L. J. (2007). Developing scientific and technological literacy through community projects. In B. Choksi \& C. Natarajan (Eds.). The epiSTEME reviews: Research trends in science technology and mathematics education (Vol. 2, pp. 179-196). Delhi, India: Macmillan India.

Sadler, T. D. (2004a). Informal reasoning regarding socioscientific issues: A critical review of research. Journal of Research in Science Teaching, 41(5), 513- 536.

Sadler, T. D. (2004b). Moral and ethical dimensions of socioscientific decision-making as integral components of scientific literacy. Science Educator, 13(1), 39-48.

Sadler, T. D. ve Zeidler, D. L. (2004). The morality of SSI: Construal and resolution of genetic engineering dilemmas. Science Education, 88, 4-27.

Sadler, T. D. ve Zeidler, D. L. (2005a). The significance of content knowledge for informal reasoning regarding socioscientific issues: Applying genetics knowledge to genetic engineering issues. Science Education, 89(1), 71-93.

Sadler, T. D. ve Zeidler, D. L. (2005b). The significance of content knowledge for informal reasoning regarding socioscientific issues: Applying genetics knowledge to genetic engineering issues. Science Education, 89(1), 71-93

Sadler, T. D., Amirshokoohi, A., Kazempour, M. ve Allspaw, K. (2006). Socioscience and ethics in science classrooms: Teacher perspectives and strategies. Journal of Research in Science Teaching, 43, 353-376.

Seggie, F. N. ve Bayyurt, Y. (2015). Nitel araştırma yöntem, teknik, analiz ve yaklaşımları. Ankara: Anı Yayıncılık.

Shibley, I. A. (2003). Using newspapers to examine the nature of science, Science \& Education, 12, 691-702.

Sigler, E. A. ve Saam, J. (2006). Teacher candidates' conceptual understanding of conceptual learning: from theory to practice. Journal of the Scholarship of Teaching and Learning, 6 (1), 118 127.

Snowman, J. ve Biehler, R. (2003). Psychology applied to teaching (10th ed.). Boston: Houghton Mifflin.

Topcu, M. S. (2011). Turkish elemantary student teachers' epistemological beliefs and moral reasoning. European Journal of Teacher Education, 34(1), 99-125.

Topçu, M. S., Muğaloğlu, E. Z. ve Güven, D. (2014). Fen eğitiminde sosyobilimsel konular: Türkiye örneği. Kuram ve Uygulamada Eğitim Bilimleri, 14(6), 1-22.

Topçu, M. S. (2017). Sosyobilimsel konular ve öğretimi (2. baskı). Ankara: Pegem Akademi.

Uşak, M. (2005). Fen Bilgisi Öğretmen Adaylarının Çiçekli Bitkiler Konusundaki Pedagojik Alan Bilgileri. Yayımlanmamış doktora tezi. Gazi Üniversitesi, Ankara.

Walker, K. ve Zeidler, D.L. (2007). Promoting discourse about socioscientific issues through scaffolded inquiry. International Journal of Science Education, 29(11), 1387-1410.

Wellington, J. ve Osborne, J. F. (2001). Language and literacy in science education. Buckingham, UK: Open University Press. 
Yıldırım, A. ve Şimşek, H. (2013). Sosyal bilimlerde nitel araştırma yöntemleri. (9. Baskı). Ankara: SeçkinYayıncılık

Zeidler, D. L., Walker, K. A., Ackett, W. A. ve Simmons, M. L. (2002). Tangled up in views: Beliefs in the nature of science and responses to socioscientific dilemmas. Science Education, 86, 343367.

Zeidler, D. L., Sadler, D. T., Simmons, M. L. ve Howes, E. V. (2005). Beyond STS: A research-based framework for socioscientific issues education. Science Education, 89, 357-377.

Zeidler, D. L. ve Sadler, D. L. (2011). An inclusive view of scientific literacy: Core issues and future directions of socioscientific reasoning. In Linder, C. Ostman, L, Roberts, D.A., Wickman, P., Erickson, G. \& MacKinnon, A. (Eds.), Promoting scientific literacy: Science education research in transaction (pp. 176-192). New York: Routledge / Taylor \& Francis Group. 


\section{Extended Summary}

\section{Purpose and Significance}

Today, the development in the field of science and technology increases rapidly and with the influence of media, scientific issues have started to occupy more important position in the public agenda. This has naturally affected science education programs all over the world and thus, educating scientifically literate individuals has become one of the main objectives of science education in today's world. Parallel to the developments in the science education, the purpose of the science curriculum, which is being implemented since 2013 in our country, was educating students to be scientifically literate individuals. To achieve this goal, "Socio-scientific issues", one of the dimensions of "Science-Technology-Society, and Environment" learning domain in the curriculum, was determined to be an important component of the curriculum for raising scientifically literate individuals. Socio-scientific issues generally refer to scientific issues concerning moral and legal dilemmas, having no full explanations and being open to dispute in the social life. It is clear that teachers carry an important role when creating learning environments that can contribute to the development of awareness for the socio-scientific issues addressed in the curriculum. Thus, it is essential for teachers to have the necessary knowledge about these issues before they start their professional careers. In this regard, it is believed that different types of media can help teachers raise scientifically literate pre-service teachers by making them aware of the interactions that take place between science and the society. The use of different types of media sources as instructional materials can enhance the quality of instruction in classes by helping preservice science teachers create connections between the events they encounter in their daily lives and their prior knowledge. The newspapers, as being one of the most easily accessible sources, can be used as teaching materials in discussing socio-scientific issues, relating science topics to daily life, and raising scientifically literate individuals. In this connection, the purpose of this study was to determine pre-service science teachers' awareness of socio-scientific issues that are considered to be the pre-requisite of science literacy.

\section{Methods}

The sample of this qualitative research is comprised of 15 third-year (junior) students (13 females and 2 males) who were selected using purposive sampling method. This research consists of two phases. In the first phase researchers followed four newspapers with the highest circulations rate for a month in 2016 and a total of 120 newspaper articles were evaluated and were found to be related to science. The second phase was an application process carried out based on the active involvement of pre-service science teachers. Within the context of this study lasting for four weeks, in the first week theoretical presentations were delivered to the pre-service science teachers about socio-scientific issues. In the second week, the pre-service science teachers were divided into five groups of three and worked in these groups until the end of the study. Each group was given 32 newspaper articles selected by the researchers and asked to determine science-related concepts in these texts and explain their meanings in writing. In the third week of the study, students were expected to answer the following questions in writing; "What are the characteristics of the socioscientific issues?" and "What are the basic requirements of a socio-scientific aspect of a topic?". In the last week of the study, groups determined which of the news texts they were given were related to the socio-scientific issues and evaluated the issues by establishing relations within the context of the previously mentioned characteristics. The data collected in this study were analysed using content analysis method and findings were obtained.

\section{Results}

The findings of the study revealed that most of the pre-service science teachers were able to determine the science-related concepts in the newspaper articles. Many of them defined the meanings of these concepts correctly/partially correctly/wrongly and some of them could not 
provide any definitions for these concepts at all. When determining whether the given issues can be considered to be socio-scientific, the pre-service science teachers have determined the following criteria including that the topics are open to dispute, are up-to-date, and presenting justifications such as reducing individual dilemmas. The pre-service teachers tried to identify the socio-scientific issues (such as Resuming Nuclear, Now is the time for influenza vaccination) from the newspaper reports after describing their characteristics related to the socio-scientific issues.

\section{Discussion and Conclusions}

Many studies in the field emphasize the inadequacy of pre-service science teachers as well as teachers' conceptual knowledge in support of presented research results (Eş, 2014; Mutlu and Özel, 2008; Uşak, 2005). The news texts used in the research process seem to address the science technology-society-environment learning field from the science curriculum and include the daily life scenes that are related to the society. In the same way, the presence of news about science in newspapers is interesting and it is emphasized that the use of newspapers in the classroom environment will facilitate the connection between science and daily life (Buluş Kırıkkaya and Bozkurt, 2012; Shibley, 2003). As a matter of fact, newspapers, which are examples of printed media, are important resources for science and technology, and for most people science can only be about reading the truth in newspapers (Levinson and Turner, 2001). In order for students to become familiar with the science concepts, it is possible to learn the concepts by preparing the templates to publish newspapers. In this study, pre-service teachers generally described socioscientific issues as they were open to dispute, lead to disagreements within the society, can be evaluated from multiple perspectives, and had simple characteristics. In the literature, it is also seen that the researchers described the socio-scientific issues within the same characteristics (Kolstø, 2001a; Nielsen, 2012; Topçu, 2015; Sadler, 2004; Sadler and Zeidler, 2004; Sadler, Amirshokoohi, Kezampouri and Allspaw, 2006; Walker and Zeidler, 2007). 